Proceedings of the 10th International Ruminant Reproduction Symposium (IRRS 2018); Foz do Iguaçu, PR, Brazil, September 16th to 20th, 2018.

\title{
Physiological mechanisms involved in maintaining the corpus luteum during the first two months of pregnancy
}

\author{
Milo C. Wiltbank ${ }^{1,2, *}$, Megan A. Mezera ${ }^{1,2}$, Mateus Z. Toledo ${ }^{1}$, Jessica N. Drum ${ }^{1,3}$, Giovanni M. Baez ${ }^{4}$, \\ Alvaro García-Guerra ${ }^{5}$, Roberto Sartori ${ }^{3}$ \\ ${ }^{1}$ Department of Dairy Science, University of Wisconsin-Madison, Madison, Wisconsin, 53706 USA. \\ ${ }^{2}$ Endocrinology-Reproductive Physiology Program, University of Wisconsin-Madison, Madison, Wisconsin, 53706 USA. \\ ${ }^{3}$ Department of Animal Science, University of São Paulo, Piracicaba, SP, 13418-900, Brazil. \\ ${ }^{4}$ Department of Agricultural and Animal Sciences, Universidad Francisco de Paula Santander, Cucuta, Colombia. \\ ${ }^{5}$ Department of Animal Sciences, The Ohio State University, Columbus, Ohio, 43210 USA.
}

\begin{abstract}
Maintenance of the corpus luteum (CL) during pregnancy is essential for continuing the elevated circulating progesterone ( $\mathrm{P} 4)$ that is required to maintain pregnancy. The mechanisms that protect the CL during early pregnancy when the non-pregnant animal would typically undergo CL regression have been extensively investigated. It is clear uterine prostaglandin F2 $\alpha$ (PGF) causes regression of the $\mathrm{CL}$ in non-pregnant ruminants and that maintenance of the $\mathrm{CL}$ during early pregnancy is dependent upon secretion of interferon-tau (IFNT) from the elongating embryo. A number of specific mechanisms appear to be activated by IFNT. Most studies indicate that there is an inhibition of oxytocin-induced secretion of uterine PGF. There is also evidence for increased resistance to PGF action, perhaps due to secretion of PGE2 and PGE1 or direct endocrine actions of circulating IFNT. These mechanisms occur concurrently and each may help to maintain the CL during the first month of pregnancy. However, during the second month of pregnancy, IFNT is no longer secreted by the embryo. Attachment of the embryo to the uterus and subsequent placentome development have been linked to silencing of expression from the IFNT gene. In addition, there is some evidence that oxytocin responsiveness of the uterus returns during the second month of pregnancy leading to substantial basal secretion of PGF and perhaps PGF pulses. There is also no evidence that the CL during the second month of pregnancy is resistant to the actions of PGF as observed during the first month. Thus, this manuscript attempts to compare the mechanisms that maintain the CL during the first and second months of pregnancy in ruminants and provides a new, speculative, physiological model for maintenance of the CL during month two of pregnancy that is distinct from the previously-described mechanisms that maintain the $\mathrm{CL}$ during the first month of pregnancy.
\end{abstract}

Keywords: corpus luteum, interferon-tau, pregnancy.

\section{Introduction}

In ruminants, progesterone $(\mathrm{P} 4)$ is produced by the corpus luteum (CL) and is essential for the original establishment and subsequent maintenance of pregnancy throughout gestation (Wiltbank et al., 2014). Likewise, the embryo/placentomes is essential for maintaining the $\mathrm{CL}$ after the first two weeks of pregnancy (Bazer et al., 1997; Spencer et al., 2007; Giordano et al., 2012). Thus, the CL and the pregnancy have a co-dependent relationship that involves both long distance (systemic) and adjacent (local pathways) interactions (Fig. 1). It is well-established that production of IFNT by the elongating embryo maintains the $\mathrm{CL}$ during the classical maternal recognition of pregnancy period in the first month of pregnancy (Bazer et al., 1997; Spencer et al., 2007; Wiltbank et al., 2016a). During the second month of pregnancy and beyond, the CL is maintained by mechanisms that remain to be elucidated (Wiltbank et al., 2016b).

Maintenance of pregnancy or, conversely, pregnancy loss can be viewed from two general perspectives (Giordano et al., 2012). First, the embryo/pregnancy may be defective and therefore it is lost, which may be positive for reproductive efficiency because, it is unlikely that a viable offspring would be produced from that pregnancy. The sooner the pregnancy can be recognized as non-viable and discarded, the sooner a new, potentially viable, pregnancy can be initiated. Alternatively, pregnancy loss could occur because the CL inappropriately regresses, resulting in loss of a viable pregnancy, with a subsequent delay in the establishment of a new viable pregnancy, and therefore a reduction in reproductive efficiency. Previous studies have quantified the amount and timing of pregnancy loss in lactating dairy cows, beef cattle, and recipients of in vitro-produced (IVP) or in vivo-derived (IVD) embryos (Santos et al., 2004; Diskin et al., 2016; Wiltbank et al., 2016a). However, no studies have clearly differentiated if a defective embryo or inappropriate CL regression underlies pregnancy loss in month one or two of pregnancy.

Pregnancy loss during the second month of gestation is substantial (Diskin and Morris, 2008; Santos et al., 2009; Diskin et al., 2016; Wiltbank et al., 2016a). To determine the current magnitude of the problem, we analyzed recent data or recently published studies that evaluated pregnancy loss in lactating dairy cattle (Table 1) or in embryo transfer recipients (Table 2). 




Figure 1. Simplified diagram illustrating that progesterone (P4) maintains the pregnancy through systemic pathways while the pregnancy, either during the first month or second month of pregnancy maintains the CL through local pathways within the utero-ovarian system.

Table 1. Studies that evaluated pregnancy/AI (P/AI) and pregnancy loss between the first (27-34 days after AI) and second pregnancy diagnosis (53-74 days after AI) in primiparous and multiparous cows or overall pregnancy loss in dairy cows from 2005 to 2017.

\begin{tabular}{|c|c|c|c|c|c|c|c|c|}
\hline \multirow[b]{2}{*}{ Reference $^{1}$} & \multirow[b]{2}{*}{ Year } & \multicolumn{2}{|c|}{$\begin{array}{c}\text { Pregnancy } \\
\text { diagnosis, day }\end{array}$} & \multicolumn{2}{|c|}{$\begin{array}{c}\mathrm{P} / \mathrm{AI} \text { at } 1 \text { st diagnosis, } \\
\%(\mathrm{n} \text { breedings })\end{array}$} & \multicolumn{2}{|c|}{$\begin{array}{c}\text { Pregnancy loss } \\
\% \text { (n pregnancies) }\end{array}$} & \multirow{2}{*}{$\begin{array}{l}\text { Overall pregnancy } \\
\operatorname{loss} \%(\mathrm{n} / \mathrm{n})\end{array}$} \\
\hline & & $1 \mathrm{st}$ & 2nd & Primiparous & Multiparous & Primiparous & Multiparous & \\
\hline Baez & 2016 & 32 & 67 & $52.2(289)$ & $42.8(327)$ & $4.6(153)$ & $8.6(140)$ & $6.5(19 / 293)$ \\
\hline Bartolome & 2005 & 30 & 55 & - & - & - & - & $8.5(10 / 118)$ \\
\hline Bartolome & 2009 & 30 & 55 & $29.1(302)$ & $39.1(416)$ & $11.4(88)$ & 10.4 (163) & $10.8(27 / 251)$ \\
\hline Bartolome & 2005 & 27 & 55 & - & - & - & - & $18.7(67 / 358)$ \\
\hline Bilby & 2013 & 32 & 60 & - & - & - & - & $10.5(60 / 569)$ \\
\hline Bisinotto & 2015 & 32 & 60 & - & - & - & - & $9.7(68 / 699)$ \\
\hline Bisinotto & 2015 & 32 & 60 & - & - & - & - & $8.0(56 / 704)$ \\
\hline Bruno & 2009 & 31 & 66 & & 35.4 (717) & & $20.1(254)$ & $20.1(51 / 254)$ \\
\hline Carvalho & 2014 & 32 & 70 & $51.0(224)$ & $46.0(377)$ & $5.2(115)$ & $7.0(172)$ & $6.3(18 / 287)$ \\
\hline Carvalho & 2015 & 32 & 67 & $57.5(240)$ & $53.3(553)$ & $9.4(138)$ & 9.7 (289) & $9.6(41 / 427)$ \\
\hline Dirandeh & 2015 & 32 & 60 & - & $41.0(900)$ & - & $15.4(369)$ & $15.4(57 / 369)$ \\
\hline Dirandeh & 2014 & 32 & 60 & - & $28.1(459)$ & - & $6.2(129)$ & $6.2(8 / 129)$ \\
\hline Dirandeh & 2015 & 32 & 60 & - & $17.7(1374)$ & - & $7.0(243)$ & $7.0(17 / 243)$ \\
\hline Giordano & 2013 & 29 & 74 & $53.8(519)$ & $40.7(565)$ & - & - & $15.5(79 / 509)$ \\
\hline Giordano & 2012 & 29 & 74 & - & - & - & - & $15.4(101 / 654)$ \\
\hline Giordano & 2012 & $29-32$ & 53 & - & - & - & - & $7.8(58 / 737)$ \\
\hline Giordano & 2015 & 31 & 67 & - & - & - & - & $11.3(37 / 326)$ \\
\hline Hernandez & 2012 & $28-32$ & $56-60$ & - & - & $12.7(173)$ & $19.5(339)$ & $17.0(88 / 512)$ \\
\hline Karakaya & 2014 & 31 & 62 & $47.6(126)$ & $28.4(176)$ & $13.3(60)$ & $8.0(50)$ & $10.9(12 / 110)$ \\
\hline Lima & 2009 & $28-32$ & 56 & - & - & - & - & $12.7(108 / 849)$ \\
\hline Lima & 2012 & 32 & 60 & - & - & - & - & $16.8(68 / 405)$ \\
\hline Lopes Jr & 2013 & 32 & 64 & - & - & - & - & $5.1(20 / 394)$ \\
\hline Martinez & 2016 & 32 & 60 & $45.3(168)$ & $43.1(274)$ & $8.3(76)$ & $11.6(118)$ & $10.3(20 / 194)$ \\
\hline Melo & 2016 & 32 & 60 & - & - & - & - & $14.3(52 / 363)$ \\
\hline Monteiro & 2015 & 32 & 60 & 35.9 (298) & $28.6(370)$ & 18.7 (107) & $17.9(206)$ & $18.3(39 / 213)$ \\
\hline Monteiro & 2014 & 34 & 62 & - & - & - & - & $8.0(39 / 487)$ \\
\hline Pereira & 2014 & 32 & 60 & - & - & - & - & $11.1(37 / 333)$ \\
\hline Pereira & 2013 & 32 & 60 & - & - & - & - & $15.7(40 / 254)$ \\
\hline Pereira & 2013 & 30 & 71 & - & - & - & - & $11.8(40 / 338)$ \\
\hline Pereira & & & & - & - & - & - & $10.7(104 / 968)$ \\
\hline Pontes & 2015 & 31 & 62 & - & - & - & - & $16.3(46 / 283)$ \\
\hline Ribeiro & 2012 & 30 & 65 & - & - & - & - & $9.5(96 / 1016)$ \\
\hline Santos & 2017 & 33 & 63 & $54.6(196)$ & $38.4(318)$ & 6.5 (107) & $9.0(122)$ & $8.3(19 / 229)$ \\
\hline Toledo & 2017 & 28 & 61 & $65.0(126)$ & $66.9(157)$ & $13.8(80)$ & $13.0(100)$ & $13.3(24 / 180)$ \\
\hline Vieira-Neto & 2017 & 32 & 60 & $40.3(3242)$ & 36.8 (4853) & $9.1(1306)$ & $14.4(1784)$ & $12.2(376 / 3090)$ \\
\hline Overall $^{2}$ & & & & $\begin{array}{c}43.0^{\mathrm{x}} \\
(2509 / 5830) \\
\end{array}$ & $\begin{array}{c}36.1^{\mathrm{y}} \\
(4280 / 11836) \\
\end{array}$ & $\begin{array}{c}9.5^{\mathrm{w}} \\
(229 / 2403)\end{array}$ & $\begin{array}{c}13.4^{z} \\
(586 / 4378) \\
\end{array}$ & $\begin{array}{c}11.7 \\
(2002 / 17145) \\
\end{array}$ \\
\hline
\end{tabular}

${ }^{1}$ Only first author listed. ${ }^{2}$ Overall P/AI and pregnancy loss of primiparous vs multiparous cows differ $(\mathrm{P}<0.01)$. 


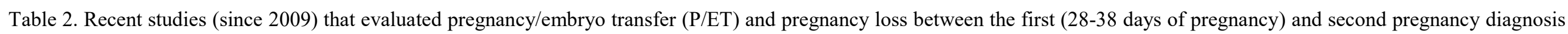
(50-60 days of pregnancy) in various breeds and categories of cattle.

\begin{tabular}{|c|c|c|c|c|c|c|c|}
\hline \multirow[b]{2}{*}{ Reference $^{1}$} & \multicolumn{3}{|c|}{$\begin{array}{c}\text { Pregnancy } \\
\text { diagnosis, day }\end{array}$} & \multirow[b]{2}{*}{ Breed } & \multirow[b]{2}{*}{ Category } & \multirow[b]{2}{*}{$\begin{array}{c}\mathrm{P} / \text { ET at } 1 \text { st diagnosis } \% \\
(\mathrm{n} / \mathrm{n})\end{array}$} & \multirow[b]{2}{*}{$\begin{array}{l}\text { Pregnancy loss } \\
\%(n / n)\end{array}$} \\
\hline & Year & $1 \mathrm{st}$ & $2 n d$ & & & & \\
\hline \multicolumn{8}{|c|}{ In vitro produced (IVP) } \\
\hline Breukelman & 2012 & 36 & 50 & Holstein & Dry cows & $52.4(76 / 145)$ & $14.5(11 / 76)$ \\
\hline Garcia-Guerra & 2017 & 32 & 60 & Holstein & Heifers & $43.4(6539 / 15052)$ & $19.8(1293 / 6539)$ \\
\hline Gatea & 2018 & 30 & 60 & Girolando & Lactating cows & $\mathrm{NR}^{2}$ & $16(21 / 131)$ \\
\hline Munhoz & 2014 & 30 & 60 & Gyr & Heifers/Lactating cows & $52.6(950 / 1807)$ & $17.9(170 / 950)$ \\
\hline Pereira & 2017 & 32 & 60 & Holstein/Girolando & Lactating cows & $31.0(100 / 323)$ & $19.0(19 / 100)$ \\
\hline Pereira & 2016 & 32 & 60 & NR & Lactating cows & $41.8(838 / 2003)$ & $19.5(163 / 838)$ \\
\hline Pohler & 2016 & 31 & 59 & Girolando & Lactating cows & NR & $16.5(47 / 285)$ \\
\hline Pontes & 2009 & 30 & 60 & Nelore & Heifers & $37.4(341 / 910)$ & $10.5(36 / 341)$ \\
\hline Pontes & 2011 & 30 & 60 & Nelore $\mathrm{x}$ Simmental & Heifers & $36.6(1974 / 5398)$ & $9.4(186 / 1974)$ \\
\hline Randi & 2015 & 30 & 60 & NR & NR & $43.5(2065 / 4749)$ & $6.1(127 / 2065)$ \\
\hline Rasmussen & 2013 & $32-35$ & 60 & Holstein & Lactating cows & $25.9(57 / 220)$ & $26.8(15 / 56)$ \\
\hline Total & & & & & & $43.5(10966 / 25209)$ & $15.6(2088 / 13355)$ \\
\hline \multicolumn{8}{|c|}{ In vivo derived (IVD) } \\
\hline Baruselli & 2011 & 30 & 60 & Holstein & Lactating cows & $39.3(2109 / 5364)$ & $20.5(432 / 2109)$ \\
\hline Breukelman & 2012 & 36 & 50 & Holstein & Dry cows & $53.9(62 / 115)$ & $4.8(3 / 62)$ \\
\hline Pereira & 2013 & 28 & 60 & Holstein & Lactating cows & $44.4(216 / 487)$ & $17.6(38 / 216)$ \\
\hline Pontes & 2009 & 30 & 60 & Nelore & Heifers & $45.6(132 / 289)$ & $9.0(12 / 132)$ \\
\hline Rodrigues & 2010 & 30 & 60 & Holstein & Lactating cows* & $43.4(159 / 366)$ & $7.5(12 / 159)$ \\
\hline Vasconcelos & 2011 & 28 & 60 & Holstein & Lactating cows & $45.4(298 / 657)$ & $16.4(49 / 298)$ \\
\hline Wallace & 2011 & $31-33$ & $55 / 59$ & Beef mixed & Mature cows & $55.6(198 / 356)$ & $3.5(7 / 198)$ \\
\hline Total IVD & & & & & & $41.6(3174 / 7634)$ & $17.0(541 / 3174)$ \\
\hline
\end{tabular}

*Repeat breeders. ${ }^{1}$ Only first author listed. ${ }^{2} \mathrm{NR}=$ not reported. 
In lactating dairy cows, analysis of studies from 2005 to 2017 demonstrated an average pregnancy loss of $11.7 \%$ (2,002 losses of 17,145 confirmed pregnancies). In 10 of these studies, there was a direct comparison of pregnancy per $\mathrm{AI}(\mathrm{P} / \mathrm{AI})$ and pregnancy loss in primiparous and multiparous cows. Primiparous cows had $\sim 20 \%$ greater $\mathrm{P} / \mathrm{AI}$ than multiparous at first pregnancy diagnosis $(43.0$ vs. $36.1=6.9 \%$ absolute difference; $6.9 / 36.1=19.1 \%$ relative difference). However, the difference was even greater at second pregnancy diagnosis (primiparous $=38.9 \% \mathrm{vs}$. multiparous $31.3 \%$ ) due to $\sim 40 \%$ greater pregnancy loss in multiparous than primiparous cows $(3.9 / 9.5=41.1 \%)$.

Pregnancy loss is also a substantial problem in embryo transfer recipients (Table 2). Based on data from over 25,000 embryo transfers, researchers that transferred IVP embryos, had over $40 \% \mathrm{P} / \mathrm{ET}$ at the first pregnancy diagnosis with subsequent loss of $15.6 \%$ of confirmed pregnancies during the second month. Published studies with IVD embryos also had over $40 \%$ $\mathrm{P} / \mathrm{ET}$ at first pregnancy diagnosis and $17 \%$ pregnancy loss during second month of pregnancy. These studies were not direct comparisons of IVP $v s$. IVD embryos but are shown to illustrate that pregnancy loss is a substantial problem in either IVP or IVD embryo transfer. Clones have even more problems in this period, with $\sim 50 \%$ of confirmed pregnancies lost during the second month (Sala et al., 2018; University of Wisconsin-Madison and ST Technology; unpublished; 51.9\%; 82/158). Thus, the second month of pregnancy is a pivotal period for pregnancy loss and could be a substantial area of opportunity, particularly if the problem is due to inappropriate regression of the CL during this period.

In cattle, if pregnancy does not occur, regression of the CL is initiated between day 16 and 25 after ovulation due to secretion of pulses of PGF from the uterus in response to circulating oxytocin pulses (Ginther et al., 2012; Spencer and Hansen, 2015; Wiltbank et al., 2016b). In pregnant cattle, during this same time period (i.e. during the first month of pregnancy) the $\mathrm{CL}$ does not undergo regression due to the actions of IFNT which is secreted by the elongating embryo near the time when luteolysis would be expected to occur (Thatcher et al., 1989; Plante et al., 1991; Meyer et al., 1995; Spencer and Bazer, 1996).

However, the mechanisms that maintain the CL during the second month of pregnancy are incompletely defined. This is despite the potential practical value of this research since it could lead to a rational method for reducing the substantial and economically-costly effects of pregnancy loss during this pivotal period. Unraveling these mechanisms could also provide intriguing fundamental biological information that could be of value in other species, including humans. This review will explore four key principles related to maintenance of CL during the first month of pregnancy including: 1) involvement of local pathways, 2) role of IFNT, 3) patterns of uterine PGF secretion, and 4) resistance to PGF action. We will then review these same potential mechanisms in maintaining CL during month two of pregnancy and perhaps later pregnancy. Our purpose in writing this review is to stimulate research on maintenance of the $\mathrm{CL}$ after the original maternal recognition of pregnancy period.

\section{Local utero-ovarian pathways in protection of the CL during pregnancy}

\section{First month of pregnancy}

The local pathways for maintenance of the CL during pregnancy are interconnected with the local pathways that produce regression of the CL during the normal estrous cycle. Early studies demonstrated that the non-pregnant uterus was the initiator of the luteolytic process in the guinea pig (Loeb, 1927). Studies in ruminants also found that removal of the uterus greatly prolonged, perhaps indefinitely, the lifespan of the CL, demonstrating the pivotal role of the uterus in luteolysis (Wiltbank and Casida, 1956). In addition, ipsilateral (uterine horn on same side as CL) hysterectomy invariably prolonged the lifespan of the $\mathrm{CL}$, while contralateral (opposite side from CL) hysterectomy consistently failed to affect CL lifespan (Inskeep and Butcher, 1966). This clearly demonstrated that local pathways between uterus and ovary were involved in initiating CL regression. The ovarian artery in ruminants is extremely convoluted and in close apposition to the uterine vein, thus allowing transfer of the uterine luteolysin, PGF, to the ovarian artery (Ginther and Delcampo, 1974; Mapletoft et al., 1976a). Elegant vascular anastomoses studies were done by exchanging the uterine veins after unilateral hysterectomy. These studies demonstrated that the intact uterine horn secreted a luteolysin into the uterine vein that subsequently diffused, through a local pathway, to the ovarian artery and caused luteolysis (Mapletoft et al., 1976a). Nevertheless, well-designed physiological studies done in sheep during the late luteal phase and following infusion of a low dose of oxytocin indicate that there are multiple pathways by which PGF secreted from the uterus can reach the CL (Bonnin et al., 1999). Determinations of PGF flow rates from the uterus, into the lungs and subsequently arriving at the ovary were done by catheterizing the uterine vein, pulmonary artery, femoral artery, and ovarian artery near the ovarian hilus (distal ovarian artery). Treatment with oxytocin increased PGF concentrations in uterine vein $(3,811 \mathrm{pg} / \mathrm{ml})$, pulmonary artery (before lungs; 224 $\mathrm{pg} / \mathrm{ml}$ ), femoral artery (after lungs; $18 \mathrm{pg} / \mathrm{ml}$ ), and distal ovarian artery $(42 \mathrm{pg} / \mathrm{ml})$. Only $0.05 \%$ of uterinesecreted PGF reached the ovary $(1 / 2000$ of PGF released) with one-third of the PGF arriving rapidly by a systemic route (PGF not metabolized in lungs) and twothirds arriving by slower routes involving local diffusion (Bonnin et al., 1999). Thus, the majority of PGF involved in regressing the CL arrives through local mechanisms, although some PGF may arrive from systemic circulation during a PGF pulse.

There are now multiple types of evidence that uterine-derived $\mathrm{PGF}$ is the definitive initiator of $\mathrm{CL}$ regression in ruminants and that $\mathrm{PGF}$ crosses from uterine vein to ovarian artery through local pathways that initiate the luteolytic process (Knickerbocker et al., 
1988; Bonnin et al., 1999; Wiltbank et al., 2016b). Studies using $\left[{ }^{3} \mathrm{H}\right]-\mathrm{PGF}$ demonstrated that during PGF pulse peak, sufficient PGF is transported from uterine vein to ovarian artery to initiate the luteolytic process (Lamond et al., 1973; McCracken et al., 1981). Indeed, intrauterine treatment with pulses of PGF, that mimic the natural PGF pulses, can induce CL regression that resembles natural luteolysis (Schramm et al., 1983; Ginther et al., 2009; Atli et al., 2012; Ochoa et al., 2018). Transport of PGF between the utero-ovarian vein and the ovarian artery involves a specific $\mathrm{PG}$ transporter, termed SLCO2A1 or OATP2A1 (Kanai et al., 1995; Schuster, 1998, 2002) that has 12transmembrane domains and provides efficient and specific transport of PGF and PGE between these vessels (Lee et al., 2010, 2013; McCracken et al., 2011). The remainder of PGF continues to be transported by the uterine vein into the systemic circulation, the heart, with eventual passage through the lungs in which $\sim 88 \%$ of PGF will be metabolized (Bonnin et al., 1999), primarily to the inactive PGF metabolite (PGFM) by the enzyme prostaglandin dehydrogenase (PGDH). Thus, luteolysis is initiated at days $17-20$ of the normal bovine estrous cycle due to uterine secretion of PGF pulses. Some PGF arrives at the ovary, primarily through local pathways, and activates important molecular and cellular pathways that ultimately lead to CL regression (Davis and Rueda, 2002; Atli et al., 2012; Maalouf et al., 2014; Ochoa et al., 2018; Pate and Hughes, 2018).

Similar vascular anastomoses experiments demonstrated that pregnancy also maintains the CL through local pathways involving transport from uterine vein to ovarian artery. For example, transfer of embryos into a surgically-isolated uterine horn resulted in CL regression if the embryo was transferred contralateral to $\mathrm{CL}$, but CL was maintained if embryo was transferred ipsilateral to the pregnancy in cows (Del Campo et al., 1977) or ewes (Moor, 1968). In surgically-isolated horns, anastomoses of uterine veins from gravid to nongravid side resulted in maintenance of CL on non-gravid side in both ewes (Mapletoft et al., 1975) and cows (Del Campo et al., 1980). This demonstrated that the pregnancy signal was local and not systemic and was carried in the local uterine vein. Other experiments were done with anastomoses of the ovarian artery from gravid to non-gravid side resulting in CL maintenance on nongravid side (Mapletoft and Ginther, 1975; Mapletoft et al., 1976b) demonstrating that the pregnancy signal passed from uterine vein to ovarian artery, only on the same side as the pregnancy (Fig. 1).

Local pathways for CL maintenance during second month of pregnancy

Previous researchers stated (Bridges et al., 2000), "a local relationship between the ovary bearing the CL and the embryo/fetoplacental unit still exists during the 2nd month of pregnancy" and we support this idea. The primary evidence that there is a local relationship comes from studies that have induced accessory $\mathrm{CL}$ on the contralateral or ipsilateral ovary during pregnancy. In one study (Lulai et al., 1994), ten pregnant beef heifers were treated on days 30-35 of pregnancy with progestin implants, to maintain pregnancy, the original $\mathrm{CL}$ was regressed using cloprostenol, and heifers were given two treatments with LH to induce accessory CL. All heifers ovulated and had an accessory CL; however, half of these heifers regressed this CL by 15-17 days after LH treatment (day 45-50 of pregnancy). Of particular interest, the accessory CL was contralateral to the pregnancy in all five of the heifers that regressed, whereas, four of five of the heifers that maintained their CL had an accessory CL that was ipsilateral to the pregnancy (Lulai et al., 1994). Similarly, induction of an accessory CL on days 29 to 59 of pregnancy was sufficient to maintain the pregnancy in 20 of 27 cows that had accessory CL that were ipsilateral to the pregnancy but maintained pregnancy in 0 of 5 cows that had accessory CL contralateral to the pregnancy (Bridges et al., 2000). Thus, an induced CL contralateral to the pregnancy is not maintained and does not maintain the pregnancy during the second month.

Our research group induced accessory CL in lactating cows by treatment with GnRH on day 5 after AI (Baez et al., 2017). In this model, 65.4\% of cows (234/358) ovulated to the GnRH and formed an accessory CL. In pregnant cows, the accessory CL ipsilateral to the pregnancy rarely regressed (8/67), however when the accessory CL was contralateral to the pregnancy, most CL regressed $(66.2 \% ; 86 / 130)$ even though the pregnancy and original ipsilateral CL were maintained. Timing of contralateral CL regression is particularly relevant with only $25.6 \% \quad(22 / 86)$ of contralateral $\mathrm{CL}$ regressions occurring during the first month and 74.4\% (64/86) happening during the second month of pregnancy $(\mathrm{P}<0.0001$; Baez et al., 2017). One interesting question is why some accessory CL regression happened during the normal time of maternal recognition of pregnancy (i.e. first month of pregnancy) while most happened during the second month. By day 18-20 of pregnancy, the whole gravid horn is filled by the elongating embryo and it extends into the contralateral horn during the next few days of pregnancy (Chang, 1952). It seems likely that the elongating embryo and IFNT will readily migrate into the contralateral horn in cows with a normal size uterus, such as heifers and primiparous cows. Interestingly, cows that had accessory CL regression during the first month of pregnancy were primarily multiparous cows. Multiparous cows have a much larger uterus than primiparous cows and fertility decreases as uterine size increases (Baez et al., 2016; Young et al., 2017). The coverage of the contralateral horn by embryonic membranes might be affected by uterine size and this may determine if early contralateral CL regression will occur. Nevertheless, most cows had contralateral, accessory CL regression during the second month of pregnancy (Baez et al., 2017). We also induced accessory $\mathrm{CL}$ in heifers and, although no ipsilateral accessory CL regressed, almost all contralateral accessory CL regressed and this occurred primarily during the second month of pregnancy (Baez, Garcia- 
Guerra, Wiltbank, 2018, University of WisconsinMadison : unpublished). Thus, there is a second distinct period of either luteolysis or CL protection happening between days 30-60 of pregnancy, regulated by local, but likely distinct, pathways from those that have been described during the first month of pregnancy.

\section{Role of embryonic production of IFNT in maintenance of $\mathbf{C L}$}

In cyclic ewes, intrauterine infusion of homogenates or secreted proteins from day 14-15 embryos extended CL lifespan, while, homogenates of day 21-25 embryos did not alter CL lifespan (Rowson and Moor, 1967; Godkin et al., 1984b), demonstrating the limited interval during pregnancy when the CLmaintaining signal is secreted by the conceptus. The active principal in the homogenates was heat and protease-labile, and had properties consistent with a low molecular weight protein (Rowson and Moor, 1967; Martal et al., 1979; Godkin et al., 1982). Later studies showed that a single protein, initially called ovine or bovine trophoblast protein-1 but later IFNT, was solely responsible for maintenance of the CL during pregnancy in ruminants (Godkin et al., 1984a, 1997; Thatcher et al., 1984).

Thus, during the critical period, days 17 to 25 in cattle or day 13-21 in sheep, the embryo is dramatically elongating and secreting IFNT, the definitive signal for CL maintenance during early pregnancy (Roberts, 1996; Bazer et al., 1997). In the uterus, INFT acts in a paracrine manner to prevent expression of estrogen receptor alpha and oxytocin receptor in luminal epithelial cells of the endometrium and superficial glandular epithelium, thereby altering response to oxytocin and release of luteolytic pulses of PGF (Spencer et al., 2007). Interferon-tau also stimulates expression of specific genes, termed interferon-stimulated genes (ISG) in the uterus (Johnson et al., 1999; Hansen et al., 2013) although their role in maintenance of the CL has not been clearly defined.

In sheep, IFNT is not secreted by morula stage embryo but expression is detected in day 8 blastocysts with dramatic increases as the embryo begins to expand and elongate (Farin et al., 1990; Ealy et al., 2001). Substantial IFNT protein secretion is observed on day 12-13 of pregnancy, with 27-fold increases between days $13-17$, with a subsequent decrease of $50 \%$ by day 21 (Hansen et al., 1985). The mRNA for IFNT is maximal on day 14 of ovine pregnancy and is related to expression of two genes, IFNT1 and IFNTc1 (Kim et al., 2018). The transcription regulatory pathways for induction of IFNT in the elongating embryo are welldescribed with ETS2 as the master regulator, combined with activation of a nearby AP-1 site and a DLX3 binding site (Ezashi and Imakawa, 2017). Maximal IFNT protein secretion occurs 2-3 days later with subsequent decreases in both IFNT mRNA and protein expression (Nojima et al., 2004). There is disappearance of IFNT mRNA and protein by days 20-23 of ovine pregnancy (Godkin et al., 1982; Guillomot et al., 1990).

One of the more interesting recent findings is the clear demonstrations that IFNT escapes the uterus and induces ISG expression in peripheral tissues such as the CL (Oliveira et al., 2008; Bott et al., 2010) and peripheral blood cells (Gifford et al., 2007; Shirasuna et al., 2012). Elegant experiments were done in which IFNT was delivered into the uterine vein $(20 \mu \mathrm{g} /$ day $)$ or jugular vein $(200 \mu \mathrm{g} /$ day $)$. These treatments increased expression of a number of genes in the $\mathrm{CL}$ including ISGs and cell survival genes (BCL2L1, Bcl-xL, AKT, and XIAP) and decreased PGF receptor expression (Antoniazzi et al., 2013). In addition, ewes were challenged with a single injection of PGF $(4 \mathrm{mg} / 58 \mathrm{~kg}$ body weight, i.m.). Ewes receiving infusions of BSA, as a control, had a decrease in circulating $\mathrm{P} 4$ to about $30 \%$ of control ewes that were not treated with PGF; however, IFNT-treated ewes that were also treated with PGF had only a small decrease in circulating P4 and a return to control values by $48 \mathrm{~h}$ after PGF treatment (Antoniazzi et al., 2013). Thus, IFNT has clear actions within the uterus to decrease uterine PGF secretion. Embryonic IFNT also escapes the uterine lumen, acting directly on the CL, potentially to directly suppress the luteolytic actions of PGF on the CL. The actions of IFNT directly on the CL could be independent or synergistic with the actions of IFNT in the uterus.

Studies indicate decreased IFNT production after 3 weeks of pregnancy in sheep and an absence of IFNT in the second month of pregnancy in both cattle and sheep (Ealy and Yang, 2009; Ezashi and Imakawa, 2017). This sudden drop in IFNT mRNA occurs concurrently with attachment of the trophectoderm to the uterus (Guillomot et al., 1990). The mechanisms are temporally linked to placental development and uterine attachment and these processes may mediate the reduction in IFNT expression. It is known there is increased DNA methylation in the 5' flanking region of the IFNT gene in $\mathrm{CpG}$ islands that are proximal to the IFNT-010 gene (Nojima et al., 2004). Culture of ovine embryos with a DNA methylation inhibitor results in no change in IFNT secretion in day 14 embryos but increased IFNT mRNA in day 17 embryos (Nojima et al., 2004). Conversely, acetylation of histone $\mathrm{H} 3$ was observed in the IFNT gene near the CDX2-binding site on days 14-16 when IFNT expression was elevated but acetylation dramatically declined as the embryo attached to the uterine wall and IFNT declined (Sakurai et al., 2010). Finally, the transcription factor EOMES has also been implicated in IFNT gene suppression since it increases near time of IFNT gene silencing and binds the coactivator CREBBP, thereby disrupting activation of the AP1 binding site in the 5' flanking region of IFNT genes (Sakurai et al., 2013). Thus, increased EOMES protein combined with declining histone acetylation and increased DNA methylation of the upstream region of the IFNT gene are linked to silencing of IFNT gene transcription as the embryo develops beyond day 17 of ovine pregnancy (Ezashi and Imakawa, 2017).

In cattle, there are some results that corroborate the timing of IFNT expression and subsequent silencing during early pregnancy. Expression of ISGs has been used as an indirect pregnancy marker at 16 to 22 days 
after AI (Romero et al., 2015; Wijma et al., 2016; Wiltbank et al., 2016a) with a subsequent decrease near the expected time of conceptus attachment to the uterine lining. Kizaki et al. (2013) collected bovine blood samples from days 0 to 28 after AI and evaluated expression of ISGs using qPCR and microarray of mRNA from peripheral blood leukocytes. As pregnancy progressed (between days 21-28), peripheral blood leukocytes had a decrease in expression of ISGs, such as ISG15, MX1, MX2, and OAS1. Moreover, in another study (Pugliesi et al., 2014), the abundance of ISG mRNA in maternal peripheral blood mononuclear cells (PBMC) peaked on day 20 and then had a sharp decrease, especially after day 30 post-AI in pregnant cows. Thus, in both cattle and sheep, most of the evidence indicates that IFNT is high during the maternal recognition of pregnancy period but then decreases to minimal secretion prior to the second month of pregnancy.

\section{Alterations in oxytocin-induced PGF pulses during pregnancy}

\section{Patterns of PGFM during first month of pregnancy}

The PGF patterns in ruminants are the result of communication between multiple organs using multiple hormones. The uterus is the central player and the source of PGF secretion. However, the posterior pituitary that releases pulses of oxytocin throughout the day is the source of the pulsatile pattern. Levels of oxytocin receptor in the uterus vary throughout the cycle, decreasing mid cycle, and increasing at day 17 through 21 in non-pregnant cows, with temporal association to uterine PGF secretion (Fuchs et al., 1990; Mann and Lamming, 2006). The cascade of events that ultimately leads to expression of uterine oxytocin receptors involves an initial down-regulation of endometrial P4 receptors after continuous exposure to P4 during the luteal phase (Wathes et al., 1996; Spencer et al., 2004). This produces an up-regulation of uterine estrogen responsiveness, which, after activation of the estrogen receptor (ESR1) by circulating estradiol (E2) from a developing follicle, generates increased expression of oxytocin receptors (Ivell et al., 2000; Mann et al., 2001; Kieborz-Loos et al., 2003; Fleming et al., 2006). The key role of follicular E2 is highlighted by the delay in luteolysis when follicular E2 is reduced by either follicular aspiration (Araujo et al., 2009) or inhibition of follicle growth with steroid-stripped follicular fluid (Salfen et al., 1996). The essential role of oxytocin is evidenced by inhibition of PGF secretion and delay in luteolysis by treatment with an oxytocin receptor antagonist (Mann et al., 2003). Binding of oxytocin to its receptor in the uterus stimulates PGF production via stimulation of both Phospholipase A2 and C (Burns et al., 1997a), releasing arachidonic acid that is subsequently converted to $\mathrm{PGH} 2$ by prostaglandin $\mathrm{H}$ synthase-2, which is also induced by oxytocin (Burns et al., 1997b).

Pulsatile secretion patterns of PGF have generally been evaluated by serial evaluations of the PGF metabolite (PGFM) throughout the process of CL regression (Wolfenson et al., 1985; Silvia and Raw, 1993; Shirasuna et al., 2004). While the pulsatile nature of these patterns is a consistent finding in all of these studies, the number of pulses and day when the pulses begin varies between animals. While CL regression can be triggered with a single large dose of exogenous PGF, the pulsatile nature of PGF secretion in the physiologic state has been shown to be required for regression when using smaller doses of PGF which more closely reflect the physiologic amounts present during regression (Ginther et al., 2009).

The PGFM concentrations have also been evaluated in early pregnant ruminants, near the time when luteolysis would normally occur in non-pregnant animals but fewer studies and inconsistent results have been reported. In one study (Lewis et al., 1977), there were no detectable differences in mean concentrations of PGFM in blood from the jugular vein in pregnant vs non-pregnant ewes from day 11-16. However, in another study (Zarco et al., 1988) mean concentrations of PGFM in pregnant ewes were greater than nonpregnant ewes on days 13-17. This study also provided some evidence for PGFM pulses in pregnant ewes, though they were of lower amplitude and less frequent than pulses documented in non-pregnant ewes (Zarco et al., 1988). In the cow, one study (Kindahl et al., 1976), failed to observe increases in PGFM concentrations or pulses of PGFM in pregnant animals during the time when luteolysis would be occurring in non-pregnant animals. However a recent study (Pinaffi et al., 2018), described statistically-detectable PGFM pulses in pregnant heifers during this same time period, although the amplitude of PGFM pulses was much lower in pregnant than non-pregnant cows. There have been fewer studies done in goats, however, no pulses of PGFM were detected in pregnant does (Fredriksson et al., 1984).

While not directly measuring PGFM production, there is documentation that from days 17-21 of bovine pregnancy there are decreased endometrial oxytocin receptors (Fuchs et al., 1990). In ruminants, IFNT during the first month of pregnancy decreases expression of oxytocin receptors in endometrium and this mechanism appears to underlie the decrease in uterine oxytocin receptors during early pregnancy and inhibition of oxytocin-induced PGF secretion from the uterus (Jenner et al., 1991; Asselin et al., 1997; Dorniak et al., 2011; Antoniazzi et al., 2013; Romero et al., 2015). It appears that IFNT does not prevent oxytocin receptor gene transcription directly, however, IFNT inhibits ESR1 transcription in vitro, preventing estrogen from being able to upregulate oxytocin receptor, and thereby blocking luteolytic amounts of PGF from being synthesized in pregnant animals (Spencer and Bazer, 1996; Spencer et al., 1996; Fleming et al., 2006). Consequently, there is decreased PGF in the uterine vein and ovarian artery and decreased pulsatile secretion of PGF by the uterus during early pregnancy (Arosh et al., 2004; Dorniak et al., 2011). Thus, in Fig. 2 is shown the postulated difference in PGFM secretion patterns during the period encompassing the normal time of luteolysis in non-pregnant cows or a similar time of early pregnancy (Fig. 2). 

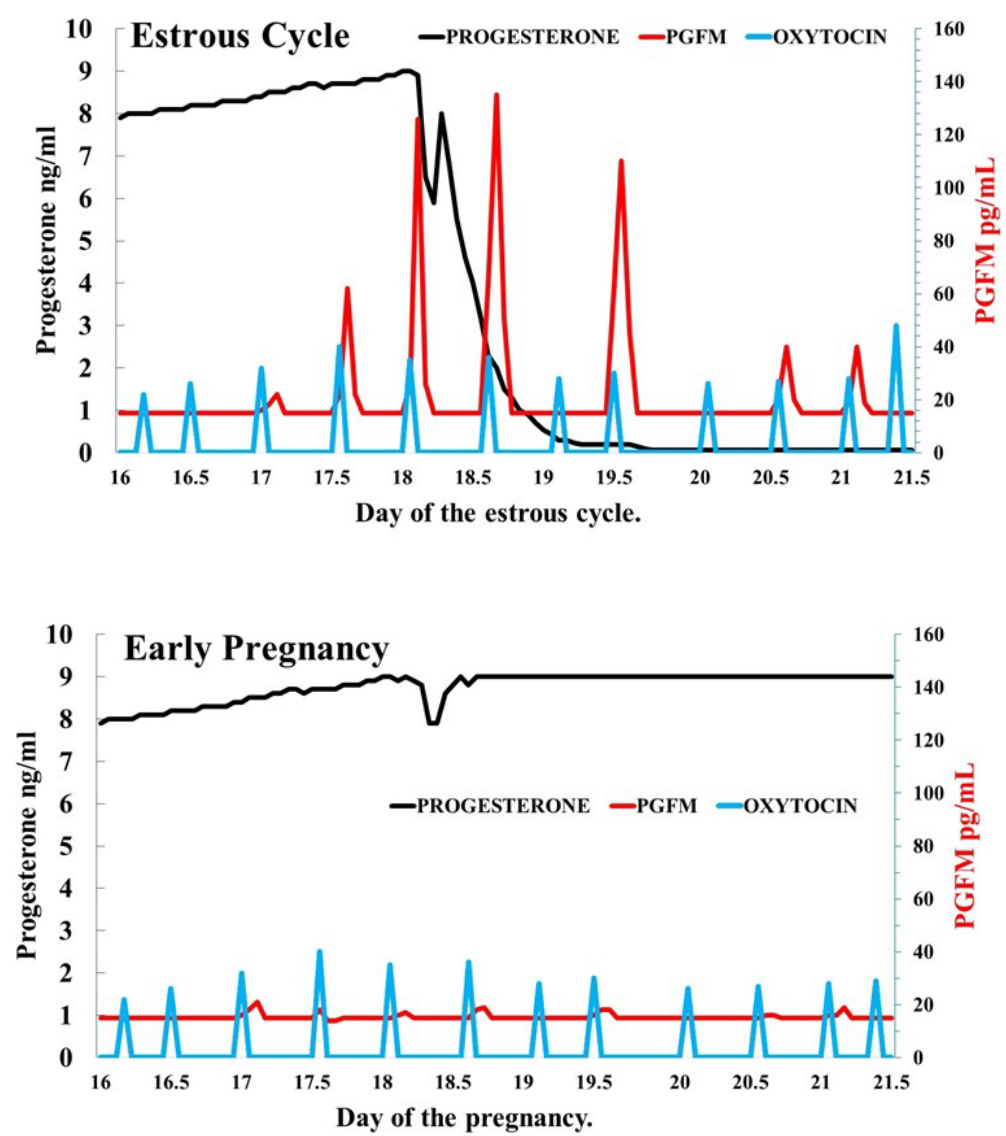

Figure 2. Simplified model for the patterns of PGFM, progesterone, and oxytocin in cattle during the late estrous cycle when luteolysis is occurring or during the same time in early pregnancy.

\section{Patterns of PGFM during second month of pregnancy}

Very little characterization of PGF patterns has occurred in ruminants during the second month of pregnancy. There is evidence that signaling pathways involved in PGF production become reestablished in the uterus and are present during month two of pregnancy. This idea is primarily supported by studies that used oxytocin challenges. During early pregnancy, oxytocin challenge on day 18 increased PGFM at $60 \mathrm{~min}$ in nonpregnant but not in pregnant heifers (Parkinson et al., 1990; Robinson et al., 1999). One study evaluated if this oxytocin response returns after the first month of pregnancy. Fuchs et al. challenged cows at known stages of gestation $(50,150,250$, or 280 days) with 10 or $100 \mathrm{IU}$ oxytocin, and measured circulating oxytocin and PGFM during the next $3 \mathrm{~h}$ (Fuchs et al., 1996). Circulating oxytocin concentrations in plasma were not affected by gestation length, however PGFM increased after oxytocin challenge as dose and time of pregnancy increased. For example, at day 280 there was 7 -fold greater increase in circulating PGFM than on day 50, although on day 50 there was a clear increase in PGFM after 100 IU of oxytocin. In addition to the oxytocin challenge, presence of intercaruncular endometrial oxytocin receptors were found at day 50 of pregnancy, suggesting the uterus is capable of responding to oxytocin stimulation with PGF production during the second month of pregnancy (Fuchs et al., 1996).

Another study evaluated this topic by maintaining pregnancies for the first month of pregnancy using exogenous progestins and by inducing an accessory CL during the second month of pregnancy. Cows on days 31-35 of pregnancy had a tendency to maintain the pregnancy at a greater rate if they produced more PGFM, as measured in blood from the posterior vena cava, and these cows also had greater circulating P4 (Bridges et al., 2000). This study also reported constant secretion of PGF, rather than secretory episodes in samples taken hourly during a $10 \mathrm{~h}$ period (Bridges et al., 2000). However, it is possible that the multiple treatments done in this study, such as regression of the original CL and formation of an accessory CL, may have had some residual effects on the PGF secretion patterns.

Recent data from our group (Drum, Wiltbank, Sartori, 2018; University of Wisconsin-Madison; unpublished) showed that the upregulation of oxytocin receptors occurs even earlier during pregnancy. By day 25 after $\mathrm{AI}$ in pregnant lactating dairy cows, there was 3 -fold increase in circulating PGFM concentrations 30 min after treatment with 50 IU oxytocin i.m. but no detectable PGFM increase at day 18 in pregnant cows. The response to oxytocin challenge was increased as pregnancy progressed until day 53-60. Moreover, no cow aborted after oxytocin treatment, despite substantial increases in circulating PGFM. These intriguing data argue that in the absence of IFNT after day 18 to 21 of pregnancy, endometrial oxytocin receptors increase, allowing for PGF release in response to oxytocin.

Thus, there are two distinct models for 
circulating PGFM during second month of pregnancy: 1) PGFM pulses are present during the second month of pregnancy (Fig. 3A), consistent with the presence of uterine oxytocin receptors and oxytocin-induced PGFM secretion in pregnant cows after day 25 (Fuchs et al.,
1996) or 2) no pulses of PGF during the second month of pregnancy, consistent with (Bridges et al., 2000), in spite of pulsatile oxytocin secretion (Fig. 3B). Further research will be necessary to determine which model is correct for month two of pregnancy.

\section{A. Pulsatile PGF release during month two of pregnancy:}

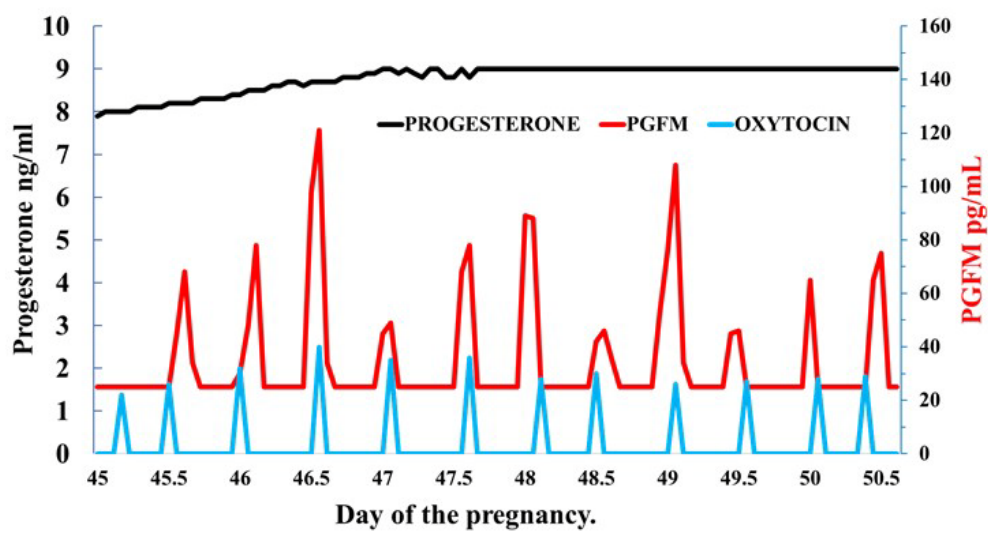

\section{B. No pulsatile PGF release during month two of pregnancy:}

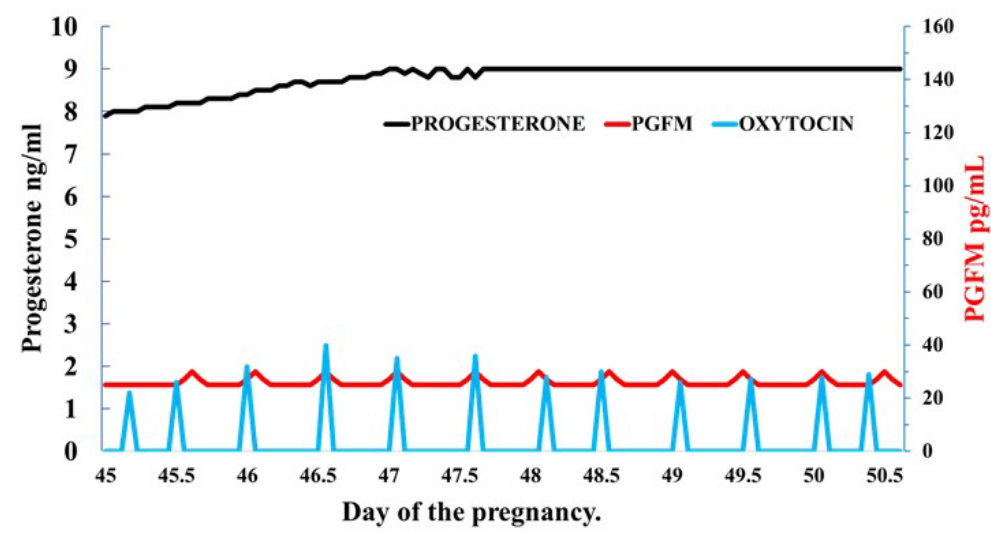

Figure 3. Speculation on two different models for the patterns of PGFM, progesterone, and oxytocin in cattle during the second month of pregnancy.

\section{Protection from PGF action during first and second month of pregnancy}

A third mechanism that may protect the CL of pregnancy is protection from luteolytic effects of the uterine luteolysin, PGF. This idea was based on the results of experiments primarily done with pregnant and non-pregnant ewes starting in the mid-1970s by three research groups. At University of Wisconsin, the research group of OJ Ginther showed that a pregnancy substance was present in either the utero-ovarian vein (UOV) or ovarian artery (OA) on the same side as the early pregnancy (before day 20) but not in the contralateral vessels and this substance had a luteotropic effect or, more accurately in our opinion, an antiluteolytic effect (Mapletoft et al., 1975,1976b). In these intricate experiments it was clearly shown that the pregnant uterus produces a substance that is transported in the UOV and subsequently in the OA and that this substance protects the CL from the luteolytic actions of endogenous or exogenous PGF.

At University of West Virginia two studies were done using a model in which a low dose of PGF was injected into the largest follicle near the CL in pregnant or non-pregnant ewes (Inskeep et al., 1975; Pratt et al., 1977a). A dose of $200 \mu \mathrm{g}$ of PGF, given on day 12 of estrous cycle or pregnancy, induced luteolysis in $11 / 14$ non-bred ewes and in 8/9 mated ewes that did not have an embryo, however, it induced luteolysis in only $3 / 8$ mated ewes with an embryo ( 2 ewes with CL regression had a very small embryo; Inskeep et al., 1975). In a second experiment (Pratt et al., 1977a), ewes on day 13 of the estrous cycle or pregnancy received $270 \mu \mathrm{g}$ of PGF-Tham salt or saline in the ipsilateral dominant follicle and luteolysis was induced in $8 / 8$ nonbred ewes and in 5/5 mated ewes without an embryo but in none of the 6 mated ewes that had an embryo.

Finally, a series of experiments were done at Colorado State University, by Bill Silvia and Gordon Niswender to evaluate whether the $\mathrm{CL}$ of early 
pregnancy was resistant to the effects of exogenous PGF. First, various doses of PGF were tested and they found that a dose of $4 \mathrm{mg} \mathrm{PGF} / 58 \mathrm{~kg}$ of body weight i.m., given on day 13 , caused CL regression in $5 / 8$ nonpregnant ewes but in $0 / 9$ pregnant ewes (Silvia and Niswender, 1984). In a subsequent experiment, they used this same PGF dose in pregnant and non-pregnant ewes on day 10 or 13 (Silvia and Niswender, 1986) and found that PGF decreased P4 in both pregnant and nonpregnant on day 10 but only regressed the CL in nonpregnant ewes on day 13. In the final experiment, ewes were treated on various days of pregnancy with the same PGF dose (Silvia and Niswender, 1986). They found no effect of PGF at $36 \mathrm{~h}$ after treatment on P4 in ewes on days 13 or 16 of pregnancy but major decreases in P4 on days 10, 26, and 30 of pregnancy. Day 19 and 22 of pregnancy had an intermediate response to this low dose of PGF. Thus, resistance to PGF is only present during a limited period of pregnancy, specifically when IFNT is being secreted by the embryo, and prior to that time or after that period there is no detectable resistance to PGF action caused by pregnancy. In this regard, a similar model was utilized to evaluate PGF resistance during endocrine delivery of IFNT in non-pregnant ewes on day 10 of the estrous cycle (Antoniazzi et al., 2013). Similar to early pregnancy, endocrine delivery of IFNT inhibited the action of PGF on circulating P4, suggesting that actions of IFNT cause the PGF resistance of early pregnancy.

There is also evidence from field studies that there is PGF resistance during early pregnancy in ewes. In one study, with 270 presumably pregnant ewes, 90 ewes were treated with PGF $(125 \mu \mathrm{g}$ cloprostenol) at 22-23 days post-service. The remaining 180 bred ewes were used as lambing controls (Reid and Crothers, 1980). Almost all controls (98.9\%) subsequently lambed, whereas, only $36.7 \%$ of the PGF-treated ewes lambed. Thus, PGF was effective in aborting most pregnant ewes $(63.3 \%)$ but about one-third of pregnant ewes displayed a resistance to PGF treatment at this stage of pregnancy. Another research group (Nancarrow et al., 1982), treated ewes on day 21 of pregnancy with $100 \mu \mathrm{g}$ of cloprostenol and found that $15 / 23$ of these ewes maintained their pregnancy. Interestingly, the ewes that had PGF resistance (i.e. maintained their pregnancy) had significantly more CL (3.2) than ewes that had CL regression (1.8) suggesting that a greater mass of embryonic tissue provides greater PGF protection. The number of CL, alone, did not provide protection from PGF since 93.5\% (43/46) of nonpregnant ewes had CL regression to this dose of PGF, and all non-pregnant ewes with more than one CL regressed their CL. Thus, the CL of early pregnancy is somewhat resistant to PGF action due to the action of a substance coming from the embryo.

A number of reports indicate that the locallyactive, luteoprotective factor is likely to be PGE2 or PGE1 (PGE) secreted from the endometrium in response to pregnancy or IFNT (Huie et al., 1981; Arosh et al., 2004,2016; Weems et al., 2011). One type of evidence is that during pregnancy, the bovine or ovine uterus produces much greater amounts of PGE than during a similar time period in non-pregnant animals (Danet-Desnoyers et al., 1995; Arnold et al., 2000; Lee et al., 2012). In addition, PGE is also produced by ovine (Hyland et al., 1982; Charpigny et al., 1997) and bovine (Saint-Dizier et al., 2011) embryos during early pregnancy. It has also been found that PGEs (Huie et al., 1981; Lee et al., 2012) can diffuse through the utero-ovarian plexus and provide local protective effects on the CL during establishment of pregnancy in sheep. Of particular importance, many studies have reported that treatment with PGE can inhibit the luteolytic actions of PGF in ovine and bovine CL (Henderson et al., 1977; Pratt et al., 1977b; Huie et al., 1981; Reynolds et al., 1981). Recently we have found that pulses of extremely low doses of PGF, delivered into the uterus, can cause complete $\mathrm{CL}$ regression and expression of an intriguing cascade of gene expression that is likely to be critical for luteolysis (Atli et al., 2012; Ochoa et al., 2018). Of special importance, simultaneous intrauterine infusion of PGE with PGF completely blocked the actions of PGF on CL regression and $\mathrm{PGF}$-induced luteal gene expression. These results indicate that either PGE blocks transport of PGF to the CL, the model that we favor, or PGE completely blocks PGF action at the CL level. Thus, the temporal secretion pattern of PGE during early pregnancy, the chemical nature of PGE that is consistent with local delivery of the antiluteolytic substance, and the biological actions of PGE to block PGF action are consistent with PGE being responsible for the observed resistance to PGF action during early pregnancy.

In contrast to early pregnancy, the CL during the second month of pregnancy does not seem to be resistant to PGF action. This is evidenced by the finding that the CL is resistant to PGF action during day 13-16 of pregnancy but loses this resistance by day 26 of pregnancy in sheep (Silvia and Niswender, 1986). Further, treatment with PGF $(500 \mu \mathrm{g}$ cloprostenol) during the second month of pregnancy (day 45-60) caused abortion in $97.9 \%$ of pregnant cows (47/48); although this same dose of PGF has not been evaluated in cows during early pregnancy (Thain, 1977).

Thus, there is substantial evidence that PGF resistance occurs during early pregnancy (IFNT period) but little evidence for PGF resistance during the second month of pregnancy (See representation in Fig. 4: CL sensitivity to PGF). Most of this evidence is from studies using pregnant ewes with a paucity of research evaluating whether PGF resistance occurs in cattle during early pregnancy. The mechanisms that underlie this PGF resistance has been investigated with no evidence for changes in PGF receptors (Wiepz et al., 1992) but substantial evidence that there are decreases in PGF synthesis and increased PGF degradation (increased PGDH enzyme) in early pregnant ewes compared to ewes at similar stages of the estrous cycle (Silva et al., 2000; Costine et al., 2007; Lee et al., 2012). 



Figure 4. Model of relative changes in hormonal concentrations (upper graph) and relative changes in responsiveness (lower graph) of the CL to PGF (based on extrapolated data from sheep in Silvia and Niswender (1986) or the uterus to oxytocin in pregnant and non-pregnant cows.

\section{Conclusions on maintenance of the CL during first or second month of pregnancy}

In Fig. 4 is shown a summary of results discussed in the previous sections and normalized to the events that occur during bovine pregnancy. During early pregnancy, circulating $\mathrm{P} 4$ is increasing in both pregnant and non-pregnant cows. Near day 18 of the estrous cycle, there is an increase in uterine responsiveness to oxytocin and a dramatic increase in PGFM pulses in non-pregnant cows that leads to rapid CL regression and initiation of a new estrous cycle. In pregnant cows during this same time period there is an increase in IFNT secretion by the early embryo which inhibits the induction of oxytocin receptor expression in the pregnant uterus and therefore uterine responsiveness to oxytocin is inhibited and oxytocin-induced PGFM pulses are inhibited. In addition, there is some evidence from early pregnant sheep that the CL becomes relatively unresponsive to PGF, perhaps due to PGE secretion from the pregnant uterus. Thus, the CL of early pregnancy is maintained by multiple mechanisms that are initiated by IFNT, seem to be primarily mediated by local pathways, and seem to involve decreased PGF secretion, perhaps decreased PGF transport, and clearly less PGF action at the CL. Figure 5 illustrates a physiological model for the three main mechanisms that are maintaining the $\mathrm{CL}$ during the classical maternal recognition of pregnancy that occurs in the first month of pregnancy.

However, the mechanisms that are protecting the CL of early pregnancy do not appear to persist into the second month of pregnancy. It appears that IFNT is no longer secreted by the embryo after the apposition and attachment process are initiated. Therefore, it appears that uterine responsiveness to oxytocin returns during the second month of pregnancy, basal PGF secretion increases and, perhaps, oxytocin-induced PGF pulses are reinitiated during the second month of pregnancy. In addition, CL responsiveness to PGF appears to return during the second month of pregnancy after the loss of IFNT. Thus, current evidence is consistent with the idea that none of the mechanisms that protect the CL during the first month of pregnancy are protecting the CL during the second month of pregnancy.

In our opinion, there are three logical explanations that could explain the maintenance of the CL during the second month of pregnancy. First, there 
is a luteoprotective substance that is secreted by the pregnancy during month two and it protects the CL either directly or by inhibiting arrival of active PGF at the CL. Since the evidence from contralateral CL regression indicates that luteal protection is locally mediated (ipsilateral CL protected, contralateral CL generally regresses), a compound like PGE would be logical. A second possibility is that PGF is secreted from the non-gravid horn in response to oxytocin but there is no PGF secretion from the gravid horn during the second month of pregnancy. This idea has not been tested and therefore remains a possibility.

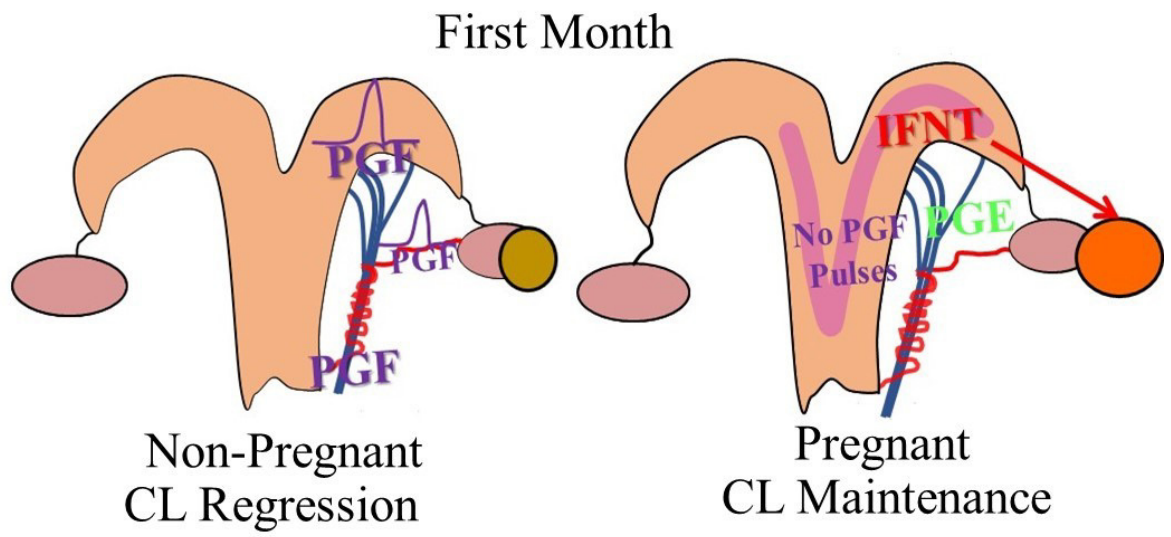

Figure 5. Physiological model depicting the three potential mechanism protecting the CL during the first month of pregnancy in ruminants. In non-pregnant ruminants, the uterus secretes prostaglandin F2 $\alpha$ (PGF) which is secreted in discrete pulses and arrives at the corpus luteum (CL) via transport from the utero-ovarian vein to the ovarian artery. In the pregnant ruminant, the elongating embryo secretes interferon-tau (IFNT) which acts to maintain the CL by: 1) suppressing PGF pulses, 2) increasing prostaglandin E (PGE) production, 3) IFNT can escape from the uterus and act directly on the CL.

The physiological model that we currently favor for protection of the CL during the second month of pregnancy is shown in Fig. 6. This model postulates that the increase in uterine blood flow that accompanies development of the placentomes also inhibits the local transport of PGF into the ovarian artery. This could be due to changes in the PGF transporter or may be related to decreased diffusion times or increased diffusion distances for PGF from the UOV to the OA. In the nongravid horn, a reduced uterine blood flow, allows local transport of PGF which is increasing during the second month of pregnancy. This leads to regression of the CL when PGF pulses that reach the ovary are of sufficient magnitude and frequency. Obviously, future research is needed to definitively evaluate the many aspects of this intriguing but highly speculative physiological model.
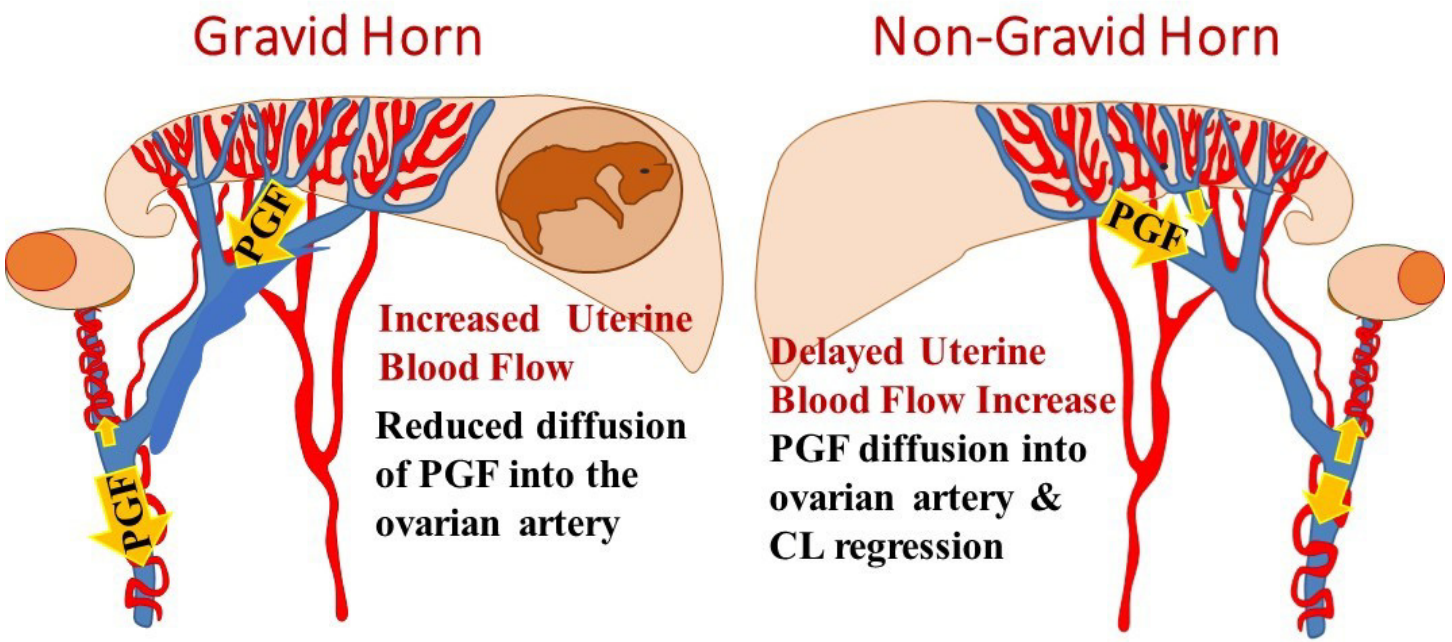

Figure 6. Current speculative physiological model depicting a mechanism that could be protecting the CL during the second month of pregnancy and possibly later pregnancy in ruminants. The gravid horn has an increased uterine blood flow during pregnancy and this high blood flow may inhibit transfer of uterine-secreted PGF to the ovarian artery. Therefore the CL would not regress because it would not be exposed to sufficient PGF, even during pulses of PGF, due to the reduction or loss of the local PGF transport system. In the contralateral horn, there is a delay in development of placentomes and the pregnancy-induced increase in uterine blood flow. Thus, contralateral CL because the local transport system for PGF will still be functional, allowing contralateral CL regression during the second month of pregnancy, as observed in previous studies. 


\section{References}

Antoniazzi AQ, Webb BT, Romero JJ, Ashley RL, Smirnova NP, Henkes LE, Bott RC, Oliveira JF, Niswender GD, Bazer FW, Hansen TR. 2013. Endocrine delivery of interferon tau protects the corpus luteum from prostaglandin F2 Alpha-induced luteolysis in ewes. Biol Reprod, 88. doi: 10.1095/biolreprod.112.105684.

Araujo RR, Ginther OJ, Ferreira JC, Palhao MM, Beg MA, Wiltbank MC. 2009. Role of follicular estradiol-17beta in timing of luteolysis in heifers. Biol Reprod, 81:426-437.

Arnold DR, Binelli M, Vonk J, Alexenko AP, Drost M, Wilcox CJ, Thatcher WW. 2000. Intracellular regulation of endometrial $\mathrm{PGF}(2 \mathrm{a})$ and $\mathrm{PGE}(2)$ production in dairy cows during early pregnancy and following treatment with recombinant interferon-tau. Domest Anim Endocrinol, 18:199-216.

Arosh JA, Banu SK, Kimmins S, Chapdelaine P, Maclaren LA, Fortier MA. 2004. Effect of interferontau on prostaglandin biosynthesis, transport, and signaling at the time of maternal recognition of pregnancy in cattle: evidence of polycrine actions of prostaglandin E2. Endocrinology, 145:5280-5293.

Arosh JA, Banu SK, McCracken JA. 2016. Novel concepts on the role of prostaglandins on luteal maintenance and maternal recognition and establishment of pregnancy in ruminants. $J$ Dairy $S c i$, 99:5926-5940.

Asselin E, Lacroix D, Fortier MA. 1997. IFN-tau increases $\mathrm{PGE}(2)$ production and $\mathrm{COX}-2$ gene expression in the bovine endometrium in vitro. Mol Cell Endocrinol, 132:117-126.

Atli MO, Bender RW, Mehta V, Bastos MR, Luo WX, Vezina CM, Wiltbank MC. 2012. Patterns of gene expression in the bovine corpus luteum following repeated intrauterine infusions of low doses of prostaglandin F2alpha. Biol Reprod, 86. doi: 10.1095/biolreprod.111.094870.

Baez GM, Barletta RV, Guenther JN, Gaska JM, Wiltbank MC. 2016. Effect of uterine size on fertility of lactating dairy cows. Theriogenology, 85:1357-1366.

Baez GM, Trevisol E, Barletta RV, Cardoso BO, Ricci A, Guenther JN, Cummings NE, Wiltbank MC. 2017. Proposal of a new model for CL regression or maintenance during pregnancy on the basis of timing of regression of contralateral, accessory $\mathrm{CL}$ in pregnant cows. Theriogenology, 89:214-225.

Bazer FW, Spencer TE, Ott TL. 1997. Interferon tau: a novel pregnancy recognition signal. Am $J$ Reprod Immunol, 37:412-420.

Bonnin P, Huynh L, L'Haridon R, Chene N, Martal J. 1999. Transport of uterine $\operatorname{PGF}(2$ alpha) to the ovaries by systemic circulation and local lymphovenous-arterial diffusion during luteolysis in sheep. J Reprod Fertil, 116:199-210.

Bott RC, Ashley RL, Henkes LE, Antoniazzi AQ, Bruemmer JE, Niswender GD, Bazer FW, Spencer TE, Smirnova NP, Anthony RV, Hansen TR. 2010. Uterine vein infusion of interferon Tau (IFNT) extends luteal life span in ewes. Biol Reprod, 82:725-735.
Bridges PJ, Wright DJ, Buford WI, Ahmad N, Hernandez-Fonseca H, McCormick ML, Schrick FN, Dailey RA, Lewis PE, Inskeep EK. 2000. Ability of induced corpora lutea to maintain pregnancy in beef cows. J Anim Sci, 78:2942-2949.

Burns PD, Graf GA, Hayes SH, Silvia WJ. 1997a. Cellular mechanisms by which oxytocin stimulates uterine PGF(2 alpha) synthesis in bovine endometrium: roles of phospholipases $\mathrm{C}$ and A(2). Domest Anim Endocrinol, 14:181-191.

Burns PD, Tsai SJ, Wiltbank MC, Hayes SH, Graf GA, Silvia WJ. 1997b. Effect of oxytocin on concentrations of prostaglandin $\mathrm{H}$ synthase-2 mRNA in ovine endometrial tissue in vivo. Endocrinology, 138:5637-5640.

Chang MC. 1952. Development of bovine blastocyst with a note on implantation. Anat Rec, 113:143-161.

Charpigny G, Reinaud P, Tamby J-P, Creminon C, Guillomot M. 1997. Cyclooxygenase-2 unlike cyclooxygenase-1 is highly expressed in ovine embryos during the implantation period. Biol Reprod, 57:10321040.

Costine BA, Inskeep EK, Blemings KP, Flores JA, Wilson ME. 2007. Mechanisms of reduced luteal sensitivity to prostaglandin F2alpha during maternal recognition of pregnancy in ewes. Domest Anim Endocrinol, 32:106-121.

Danet-Desnoyers G, Meyer MD, Gross TS, Johnson JW, Thatcher WW. 1995. Regulation of endometrial prostaglandin synthesis during early pregnancy in cattle: effects of phospholipases and calcium in vitro. Prostaglandins, 50:313-330.

Davis JS, Rueda BR. 2002. The corpus luteum: an ovarian structure with maternal instincts and suicidal tendencies. Front Biosci, 7:D1949-D1978.

Del Campo MR, Rowe RF, French LR, Ginther OJ. 1977. Unilateral relationship of embryos and the corpus luteum in cattle. Biol Reprod, 16:580-585.

Del Campo MR, Mapletoft RJ, Rowe RF, Critser JK, Ginther OJ. 1980. Unilateral utero-ovarian relationship in pregnant cattle and role of uterine vein. Theriogenology, 14:185-193.

Diskin MG, Morris DG. 2008. Embryonic and early foetal losses in cattle and other ruminants. Reprod Domest Anim, 43:260-267.

Diskin MG, Waters SM, Parr MH, Kenny DA. 2016. Pregnancy losses in cattle: potential for improvement. Reprod Fertil Dev, 28:83-93.

Dorniak P, Bazer FW, Spencer TE. 2011. Prostaglandins regulate conceptus elongation and mediate effects of interferon tau on the ovine uterine endometrium. Biol Reprod, 84:1119-1127.

Ealy AD, Larson SF, Liu L, Alexenko AP, Winkelman GL, Kubisch HM, Bixby JA, Roberts RM. 2001. Polymorphic forms of expressed bovine interferon-tau genes: Relative transcript abundance during early placental development, promoter sequences of genes and biological activity of protein products. Endocrinology, 142:2906-2915.

Ealy AD, Yang QE. 2009. Control of interferon-tau expression during early pregnancy in ruminants. $\mathrm{Am} \mathrm{J}$ Reprod Immunol, 61:95-106. 
Ezashi T, Imakawa K. 2017. Transcriptional control of IFNT expression. Reproduction, 154:F21-F31.

Farin CE, Imakawa K, Hansen TR, Mcdonnell JJ, Murphy CN, Farin PW, Roberts RM. 1990. Expression of trophoblastic interferon genes in sheep and cattle. Biol Reprod, 43:210-218.

Fleming JGW, Spencer TE, Safe SH, Bazer FW. 2006. Estrogen regulates transcription of the ovine oxytocin receptor gene through GC-rich SP1 promoter elements. Endocrinology, 147:899-911.

Fredriksson G, Kindahl H, Edqvist LE. 1984. 11Ketotetranor PGF metabolites, a suitable indicator for measuring prostaglandin release during the normal estrous cycle and early pregnancy in the goat. Anim Reprod Sci, 7:537-545.

Fuchs AR, Behrens O, Helmer H, Liu CH, Barros CM, Fields MJ. 1990. Oxytocin and vasopressin receptors in bovine endometrium and myometrium during the estrous cycle and early pregnancy. Endocrinology, 127:629-636.

Fuchs AR, Rollyson MK, Meyer M, Fields MJ, Minix JM, Randel RD. 1996. Oxytocin induces prostaglandin F-2 alpha release in pregnant cows: Influence of gestational age and oxytocin receptor concentrations. Biol Reprod, 54:647-653.

Gifford CA, Racicot K, Clark DS, Austin KJ, Hansen TR, Lucy MC, Davies CJ, Ott TL. 2007 Regulation of interferon-stimulated genes in periphera blood leukocytes in pregnant and bred, nonpregnant dairy cows. J Dairy Sci, 90.

Ginther OJ, Delcampo CH. 1974. Vascular anatomy of uterus and ovaries and unilateral luteolytic effect of uterus - cattle. Am J Vet Res, 35:193-203.

Ginther OJ, Araujo RR, Palhao MP, Rodrigues BL, Beg MA. 2009. Necessity of sequential pulses of prostaglandin F2alpha for complete physiologic luteolysis in cattle. Biol Reprod, 80:641-648.

Ginther OJ, Khan FA, Hannan MA, Beg MA. 2012 Temporal interrelationships at 15 -min intervals among oxytocin, LH, and progesterone during a pulse of a prostaglandin F2alpha metabolite in heifers. Anim Reprod Sci, 133:63-70.

Giordano JO, Guenther JN, Lopes G, Jr., Fricke PM. 2012. Changes in serum pregnancy-associated glycoprotein, pregnancy-specific protein $\mathrm{B}$, and progesterone concentrations before and after induction of pregnancy loss in lactating dairy cows. J Dairy Sci, 95:683-697.

Godkin JD, Bazer FW, Moffatt J, Sessions F, Roberts RM. 1982. Purification and properties of a major, low molecular weight protein released by the trophoblast of sheep blastocysts at day 13-21. J Reprod Fertil, 65:141-150.

Godkin JD, Bazer FW, Roberts RM. 1984a. Ovine trophoblast protein 1, an early secreted blastocyst protein, binds specifically to uterine endometrium and affects protein synthesis. Endocrinology, 114:120-130.

Godkin JD, Bazer FW, Thatcher WW, Roberts RM. 1984b. Proteins released by cultured day 15-16 conceptuses prolong luteal maintenance when introduced into the uterine lumen of cyclic ewes. $J$ Reprod Fertil, 71:57-64.
Godkin JD, Smith SE, Johnson RD, Dore JJ. 1997. The role of trophoblast interferons in the maintenance of early pregnancy in ruminants. Am J Reprod Immunol, 37:137-143.

Guillomot M, Michel C, Gaye P, Charlier N, Trojan J, Martal J. 1990. Cellular localization of an embryonic interferon, ovine trophoblastin and its mRNA in sheep embryos during early pregnancy. Biol Cell, 68:205-211.

Hansen PJ, Anthony RV, Bazer FW, Baumbach GA, Roberts RM. 1985. In vitro synthesis and secretion of ovine trophoblast protein-1 during the period of maternal recognition of pregnancy. Endocrinology, 117:1424-1430.

Hansen TR, Romero JJ, Antoniazzi AQ, Bott RC, Ashley RL, Webb BT, Henkes LE, Smirnova NP. 2013. Endocrine conceptus signaling in ruminants. Anim Reprod, 10:311-321.

Henderson K, Scaramuzzi R, Baird D. 1977. Simultaneous infusion of prostaglandin E2 antagonizes the luteolytic action of prostaglandin F2 $\alpha$ in vivo. $J$ Endocrinol, 72:379-383.

Huie JM, Magness RR, Reynolds LP, Hoyer G, Huecksteadt T, Colcord M, Stalcup B, Whysong GL, Weems CW. 1981. Effect of chronic inpsilateral or contralateral intrauterine infusion of prostaglandin E1 (PGE1) on luteal function of unilaterally ovariectomized ewes. Prostaglandins, 21:945-955.

Hyland J, Manns J, Humphrey W. 1982. Prostaglandin production by ovine embryos and endometrium in vitro. J Reprod Fertil, 65:299-304.

Inskeep EK, Butcher RL. 1966. Local component of utero-ovarian relationships in ewe. J Anim Sci, 25:11641168.

Inskeep EK, Smutny WJ, Butcher RL, Pexton JE. 1975. Effects of intrafollicular injections of prostaglandins in non-pregnant and pregnant ewes. $J$ Anim Sci, 41:1098-1104.

Ivell R, Fuchs AR, Bathgate R, Tillmann G, Kimura T. 2000. Regulation of the oxytocin receptor in bovine reproductive tissues and the role of steroids. Reprod Domest Anim, 35:134-141.

Jenner LJ, Parkinson TJ, Lamming GE. 1991. Uterine oxytocin receptors in cyclic and pregnant cows. $J$ Reprod Fertil, 91:49-58.

Johnson GA, Austin KJ, Collins AM, Murdoch WJ, Hansen TR. 1999. Endometrial ISG17 mRNA and a related mRNA are induced by interferon-tau and localized to glandular epithelial and stromal cells from pregnant cows. Endocrine, 10:243-252.

Kanai N, Lu R, Satriano JA, Bao Y, Wolkoff AW, Schuster VL. 1995. Identification and characterization of a prostaglandin transporter. Science, 268:866-869.

Kieborz-Loos KR, Garverick HA, Keisler DH, Hamilton SA, Salfen BE, Youngquist RS, Smith MF. 2003. Oxytocin-induced secretion of prostaglandin F-2 alpha in postpartum beef cows: effects of progesterone and estradiol-17 beta treatment. J Anim Sci, 81:18301836.

Kim MS, Min KS, Seong HH, Kim CL, Jeon IS, Kim SW, Imakawa K. 2018. Regulation of conceptus interferon-tau gene subtypes expressed in the uterus 
during the peri-implantation period of cattle. Anim Reprod Sci, 190:39-46.

Kindahl H, Edqvist L-E, Bane A, Granstrom E. 1976. Blood levels of progesterone and 15-keto-13,14dihydro-prostaglandin $\mathrm{F} 2 \mathrm{a}$ during the normal oestrous cycle and early pregnancy in heifers. Acta Endocrinol, 82:134-149.

Kizaki K, Shichijo-Kizaki A, Furusawa T, Takahashi T, Hosoe M, Hashizume K. 2013. Differential neutrophil gene expression in early bovine pregnancy. Reprod Biol Endocrinol, 11:6. doi: 10.1186/1477-7827-11-6.

Knickerbocker JJ, Wiltbank MC, Niswender GD 1988. Mechanisms of luteolysis in domestic livestock. Domest Anim Endocrinol, 5:91-107.

Lamond DR, Drost M, Mccracke.Ja, Lamond DR. 1973. Countercurrent transfer of prostaglandin in ewe. Prostaglandins, 3:691-702.

Lee J, McCracken JA, Banu SK, Rodriguez R, Nithy TK, Arosh JA. 2010. Transport of prostaglandin $\mathrm{F}$ (2alpha) pulses from the uterus to the ovary at the time of luteolysis in ruminants is regulated by prostaglandin transporter-mediated mechanisms. Endocrinology, 151:3326-3335.

Lee J, McCracken JA, Stanley JA, Nithy TK, Banu SK, Arosh JA. 2012. Intraluteal prostaglandin biosynthesis and signaling are selectively directed towards PGF(2alpha) during luteolysis but towards PGE(2) during the establishment of pregnancy in sheep. Biol Reprod, 87:97. doi: 10.1095/biolreprod.112. 100438.

Lee J, McCracken JA, Banu SK, Arosh JA. 2013. Intrauterine inhibition of prostaglandin transporter protein blocks release of luteolytic PGF2alpha pulses without suppressing endometrial expression of estradiol or oxytocin receptor in ruminants. Biol Reprod, 89:27. doi: 10.1095/biolreprod.112.106427.

Lewis GS, Wilson L, Jr., Wilks JW, Pexton JE, Fogwell RL, Ford SP, Butcher RL, Thayne WV, Inskeep EK. 1977. PGF2 alpha and its metabolites in uterine and jugular venous plasma and endometrium of ewes during early pregnancy. J Anim Sci, 45:320-327.

Loeb L. 1927. The effects of hysterectomy on the system of sex organs and on the periodicity of the sexual cycle in the guinea pig. Am J Physiol, 83:202-208.

Lulai C, Dobrinski I, Kastelic JP, Mapletoft RJ 1994. Induction of luteal regression, ovulation and development of new luteal tissue during early pregnancy in heifers. Anim Reprod Sci, 35:163-172.

Maalouf SW, Liu WS, Albert I, Pate JL. 2014 Regulating life or death: potential role of microRNA in rescue of the corpus luteum. Mol Cell Endocrinol, 398:78-88

Mann GE, Payne JH, Lamming GE. 2001. Hormonal regulation of oxytocin-induced prostaglandin F-2 alpha secretion by the bovine and ovine uterus in vivo. Domest Anim Endocrinol, 21:127-141.

Mann GE, Lamming GE, Scholey D, Hunter M, Pettibone DJ. 2003. Attenuation of $\operatorname{PGF}(2$ alpha) release in ewes infused with the oxytocin antagonist L368,899. Domest Anim Endocrinol, 25:255-262.

Mann GE, Lamming GE. 2006. Timing of prostaglandin F-2 alpha release episodes and oxytocin receptor development during luteolysis in the cow. Anim Reprod Sci, 93:328-336.

Mapletoft RJ, Delcampo MR, Ginther OJ. 1975. Unilateral luteotropic effect of uterine venous effluent of a gravid uterine horn in sheep. Proc Soc Exp Biol Med, 150:129-133.

Mapletoft RJ, Ginther OJ. 1975. Adequacy of main uterine vein and ovarian artery in local venoarterial pathway for uterine-induced luteolysis in ewes. $\mathrm{Am} \mathrm{J}$ Vet Res, 36:957-963.

Mapletoft RJ, Delcampo MR, Ginther OJ. 1976a.

Local utero-ovarian venoarterial pathway in cows. $J$ Anim Sci, 43:295-296.

Mapletoft RJ, Lapin DR, Ginther OJ. 1976b. Ovarian artery as final component of local luteotropic pathway between a gravid uterine horn and ovary in ewes. Biol Reprod, 15:414-421.

Martal J, Lacroix MC, Loudes C, Saunier M, Wintenberger-Torres S. 1979. Trophoblastin, an antiluteolytic protein present in early pregnancy in sheep. J Reprod Fertil, 56:63-73.

McCracken JA, Schramm W, Barcikowski B, Wilson L Jr. 1981. The identification of prostaglandin F2 alpha as a uterine luteolytic hormone and the hormonal control of its synthesis. Acta Vet Scand Suppl, 77:71-88.

McCracken JA, Lee J, Yang B, Nithy TK, Banu SK, Bazer FW, Arosh JA. 2011. Inhibition of the prostaglandin transporter protein suppresses luteolytic pulses of PGF2alpha from the ovine uterus. Biol Reprod, 85. doi.org/10.1093/biolreprod/85.s1.374.

Meyer MD, Hansen PJ, Thatcher WW, Drost M, Badinga L, Roberts RM, Li J, Ott TL, Bazer FW. 1995. Extension of corpus luteum lifespan and reduction of uterine secretion of prostaglandin F2 alpha of cows in response to recombinant interferon-tau. $J$ Dairy $S c i$, 78:1921-1931.

Moor RM. 1968. Effect of embryo on corpus luteum function. J Anim Sci, 27(suppl. 1):97-118.

Nancarrow CD, Evison BM, Connell PJ. 1982. Effect of embryos on luteolysis and termination of early pregnancy in sheep with cloprostenol. Biol Reprod, 26:263-269.

Nojima H, Nagaoka K, Christenson RK, Shiota K, Imakawa K. 2004. Increase in DNA methylation downregulates conceptus interferon-tau gene expression. Mol Reprod Dev, 67:396-405.

Ochoa JC, Penagaricano F, Baez GM, Melo LF, Motta JC, Guerra AG, Meidan R, Ferreira JCP, Sartori R, Wiltbank MC. 2018. Mechanisms for rescue of $\mathrm{CL}$ during pregnancy: gene expression in bovine $\mathrm{CL}$ following intrauterine pulses of prostaglandins E1 and F2alpha. Biol Reprod, 98:465479,

Oliveira JF, Henkes LE, Ashley RL, Purcell SH, Smirnova NP, Veeramachaneni DN, Anthony RV, Hansen TR. 2008. Expression of interferon (IFN)stimulated genes in extrauterine tissues during early pregnancy in sheep is the consequence of endocrine IFN-tau release from the uterine vein. Endocrinology, 149:1252-1259. 
Parkinson TJ, Jenner LJ, Lamming GE. 1990. Comparison of oxytocin prostaglandin-F2-alpha interrelationships in cyclic and pregnant cows. $J$ Reprod Fertil, 90:337-345.

Pate JL, Hughes CK. 2018. Integration of proteomic, transcriptomic and metabolomic data for luteal rescue in early pregnancy: role of microRNA as regulators of the corpus luteum. Anim Reprod, 15:00-00.

Pinaffi FLV, Araujo ER, Ginther OJ. 2018. Concentrations of a PGF2 alpha metabolite during pregnancy on the days that luteolysis occurs in nonbred heifers. Domest Anim Endocrinol, 62:76-82.

Plante C, Thatcher WW, Hansen PJ. 1991. Alteration of oestrous cycle length, ovarian function and oxytocininduced release of prostaglandin F-2 alpha by intrauterine and intramuscular administration of recombinant bovine interferon-alpha to cows. J Reprod Fertil, 93:375-384

Pratt BR, Butcher RL, Inskeep EK. 1977a. Antiluteolytic effect of the conceptus and of PGE2 in ewes. J Anim Sci, 45:784-791.

Pratt BR, Butcher RL, Inskeep EK. 1977b. Effect of continuous intrauterine administration of prostaglandin E2 on life-span of corpora lutea of nonpregnant ewes. $J$ Anim Sci, 48:1441-1446.

Pugliesi G, Miagawa BT, Paiva YN, Franca MR, Silva LA, Binelli M. 2014. Conceptus-induced changes in the gene expression of blood immune cells and the ultrasound-accessed luteal function in beef cattle: how early can we detect pregnancy? Biol Reprod, 91:95. doi: 10.1095/biolreprod.114.121525.

Reid RND, Crothers I. 1980. Prostaglandin-F2-Alpha for estrus synchronization or bbortion in polwarth ewes. Aust Vet J, 56:22-24.

Reynolds L, Stigler J, Hoyer G, Magness R, Huie J, Huecksteadt T, Whysong G, Behrman H, Weems C. 1981. Effect of PGE 1 or PGE 2 on PGF $2 \alpha$-induced luteolysis in nonbred ewes. Prostaglandins, 21:957-972. Roberts RM. 1996. Interferon-tau and pregnancy. $J$ Interferon Cytokine Res, 16:271-273.

Robinson RS, Mann GE, Lamming GE, Wathes DC. 1999. The effect of pregnancy on the expression of uterine oxytocin, oestrogen and progesterone receptors during early pregnancy in the cow. $J$ Endocrinol, 160:21-33.

Romero JJ, Antoniazzi AQ, Nett TM, Ashley RL, Webb BT, Smirnova NP, Bott RC, Bruemmer JE, Bazer FW, Anthony RV, Hansen TR. 2015. Temporal release, paracrine and endocrine actions of ovine conceptus-derived interferon-tau during early pregnancy. Biol Reprod, 93. doi: 10.1095/biolreprod. 115.132860

Rowson LE, Moor RM. 1967. The influence of embryonic tissue homogenate infused into the uterus, on the life-span of the corpus luteum in the sheep. J Reprod Fertil, 13:511-516.

Saint-Dizier M, Grimard B, Guyader-Joly C, Humblot P, Ponter AA. 2011. Expression of enzymes involved in the synthesis of prostaglandin E-2 in bovine in vitro-produced embryos. Zygote, 19:277-283.

Sakurai T, Bai H, Konno T, Ideta A, Aoyagi Y, Godkin JD, Imakawa K. 2010. Function of a transcription factor $\mathrm{CDX} 2$ beyond its trophectoderm lineage specification. Endocrinology, 151:5873-5881.

Sakurai T, Bai H, Bai R, Sato D, Arai M, Okuda K, Ideta A, Aoyagi Y, Godkin JD, Imakawa K. 2013. Down-regulation of interferon tau gene transcription with a transcription factor, EOMES. Mol Reprod Dev, 80:371-383.

Salfen BE, Cresswell JR, Xu ZZ, Bao B, Garverick HA. 1996. Effects of presence of a dominant follicle and estradiol on length of luteal phases in estrous cycles with two or three waves of follicular development. Biol Reprod, 54:235-235.

Santos JE, Thatcher WW, Chebel RC, Cerri RL, Galvao KN. 2004. The effect of embryonic death rates in cattle on the efficacy of estrus synchronization programs. Anim Reprod Sci, 82-83:513-535.

Santos JEP, Rutigliano HM, Sa Filho MF. 2009. Risk factors for resumption of postpartum estrous cycles and embryonic survival in lactating dairy cows. Anim Reprod Sci, 110:207-221.

Schramm W, Bovaird L, Glew ME, Schramm G, Mccracken JA. 1983. Corpus luteum regression induced by ultra low pulses of prostaglandin-F2-Alpha. Prostaglandins, 26:347-364.

Schuster VL. 1998. Molecular mechanisms of prostaglandin transport. Annu Rev Physiol, 60:221-242.

Schuster VL. 2002. Prostaglandin transport. Prostaglandins \& Other Lipid Mediators, 68-9:633-647.

Shirasuna K, Asaoka H, Acosta TJ, Wijayagunawardane MP, Ohtani M, Hayashi KG, Matsui M, Miyamoto A. 2004. Real-time dynamics of prostaglandin F2alpha release from uterus and corpus luteum during spontaneous luteolysis in the cow. Reproduction, 128:189-195.

Shirasuna K, Matsumoto H, Kobayashi E, Nitta A, Haneda S, Matsui M, Kawashima C, Kida K, Shimizu T, Miyamoto A. 2012. Upregulation of interferon-stimulated genes and interleukin-10 in peripheral blood immune cells during early pregnancy in dairy cows. J Reprod Dev, 58:84-90.

Silva PJ, Juengel JL, Rollyson MK, Niswender GD. 2000. Prostaglandin metabolism in the ovine corpus luteum: Catabolism of prostaglandin F-2 alpha (PGF(2 alpha)) coincides with resistance of the corpus luteum to PGF(2 alpha). Biol Reprod, 63:1229-1236.

Silvia WJ, Niswender GD. 1984. Maintenance of the corpus luteum of early pregnancy in the ewe. 3 . Differences between pregnant and nonpregnant ewes in luteal responsiveness to prostaglandin F2-alpha. $J$ Anim Sci, 59:746-753.

Silvia WJ, Niswender GD. 1986. Maintenance of the corpus luteum of early pregnancy in the ewe. 4. Changes in luteal sensitivity to prostaglandin F2-alpha throughout early pregnancy. J Anim Sci, 63:1201-1207.

Silvia WJ, Raw RE. 1993. Regulation of pulsatile secretion of prostaglandin-F2-alpha from the ovine uterus by ovarian steroids. J Reprod Fertil, 98:341-347. Spencer TE, Bazer FW. 1996. Ovine interferon tau suppresses transcription of the estrogen receptor and oxytocin receptor genes in the ovine endometrium. Endocrinology, 137:1144-1147. 
Spencer TE, Mirando MA, Mayes JS, Watson GH, Ott TL, Bazer FW. 1996. Effects of interferon-tau and progesterone on oestrogen-stimulated expression of receptors for oestrogen, progesterone and oxytocin in the endometrium of ovariectomized ewes. Reprod Fertil Dev, 8:843-853.

Spencer TE, Johnson GA, Burghardt RC, Bazer FW. 2004. Progesterone and placental hormone actions on the uterus: Insights from domestic animals. Biol Reprod, 71:2-10.

Spencer TE, Johnson GA, Bazer FW, Burghardt RC, Palmarini M. 2007. Pregnancy recognition and conceptus implantation in domestic ruminants: Roles of progesterone, interferons and endogenous retroviruses. Reprod Fertil Dev, 19:65-78.

Spencer TE, Hansen TR. 2015. Implantation and establishment of pregnancy in ruminants. Adv Anat Embryol Cel, 216:105-135.

Thain RI. 1977. Subsequent fertility in heifers aborted using prostaglandins at 45-60 days of pregnancy. Aust Vet J, 53:198-198.

Thatcher WW, Bartol FF, Knickerbocker JJ, Curl JS, Wolfenson D, Bazer FW, Roberts RM. 1984. Maternal recognition of pregnancy in cattle. J Dairy Sci, 67:2797-2811.

Thatcher WW, Hansen PJ, Gross TS, Helmer SD, Plante C, Bazer FW. 1989. Antiluteolytic effects of bovine trophoblast protein-1. J Reprod Fertil Suppl, 37:91-99.

Wathes DC, Mann GE, Payne JH, Riley PR, Stevenson KR, Lamming GE. 1996. Regulation of oxytocin, oestradiol and progesterone receptor concentrations in different uterine regions by oestradiol, progesterone and oxytocin in ovariectomized ewes. $J$ Endocrinol, 151:375-393.

Weems YS, Arreguin-Arevalo JA, Nett TM, Vann RC, Ford SP, Bridges PJ, Welsh TH, Lewis AW, Neuendorff DA, Randel RD, Weems CW. 2011. In vivo intra-luteal implants of prostaglandin (PG) E-1 or E-2 (PGE(1), PGE(2)) prevent luteolysis in cows. I. Luteal weight, circulating progesterone, mRNA for luteal luteinizing hormone (LH) receptor, and occupied and unoccupied luteal receptors for LH. Prostaglandins
Other Lipid Mediat, 95:35-44.

Wiepz GJ, Wiltbank MC, Nett TM, Niswender GD, Sawyer HR. 1992. Receptors for prostaglandins-F2alpha and E2 in ovine corpora lutea during maternal recognition of pregnancy. Biol Reprod, 47:984-991.

Wijma R, Stangaferro ML, Kamat MM, Vasudevan S, Ott TL, Giordano JO. 2016. Embryo mortality around the period of maintenance of the corpus luteum causes alterations to the ovarian function of lactating dairy cows. Biol Reprod, 95:112. doi:

10.1095/biolreprod.116.142075.

Wiltbank JN, Casida LE. 1956. Alteration of ovarian activity by hysterectomy. J Anim Sci, 15:134-140.

Wiltbank MC, Souza AH, Carvalho PD, Cunha AP, Giordano JO, Fricke PM, Baez GM, Diskin MG. 2014. Physiological and practical effects of progesterone on reproduction in dairy cattle. Animal, 8:70-81.

Wiltbank MC, Baez GM, Garcia-Guerra A, Toledo MZ, Monteiro PLJ, Melo LF, Ochoa JC, Santos JEP, Sartori R. 2016a. Pivotal periods for pregnancy loss during the first trimester of gestation in lactating dairy cows. Theriogenology, 86:239-253.

Wiltbank MC, Meidan R, Ochoa J, Baez GM, Giordano JO, Ferreira JCP, Sartori R. 2016 b. Maintenance or regression of the corpus luteum during multiple decisive periods of bovine pregnancy. Anim Reprod, 13:217-233.

Wolfenson D, Thatcher WW, Drost M, Caton D, Foster DB, Leblanc MM. 1985. Characteristics of prostaglandin-F measurements in the ovarian iirculation during the estrous cycle and early pregnancy in the cow. J Reprod Fertil, 75:491-499.

Young CD, Schrick FN, Pohler KG, Saxton AM, Di Croce FA, Roper DA, Wilkerson JB, Edwards JL. 2017. Short communication: A reproductive tract scoring system to manage fertility in lactating dairy cows. J Dairy Sci, 100:5922-5927.

Zarco L, Stabenfeldt GH, Quirke JF, Kindahl H, Bradford GE. 1988. Release of prostaglandin-F-2alpha and the timing of events associated with luteolysis in ewes with estrous cycles of different lengths. $J$ Reprod Fertil, 83:517-526. 